\title{
Efficiency Improvement of on-Grid Solar PV System Using Hybrid MPPT
}

\author{
Anjali Gupta, Praveen Pachauri
}

\begin{abstract}
Solar photovoltaic systems are most commonly used renewable resources nowadays. These pv cells are eco-friendly, pollution free, easy in construction and are compact in size. The solar pv cell generates electricity by simply tracking the sun rays. The main advantage of solar pv cell is that it is dependent on sun light and the sun is available everywhere. The power generated by photovoltaic cell has less efficiency. Thus, this paper proposes the hybrid maximum power point tracker for improving the efficiency of generated energy of grid connected solar pv system. 1
\end{abstract}

Keywords- Hybrid MPPT (Maximum PowerPoint Tracking), solar photovoltaic cell, solar panel.

\section{INTRODUCTION}

With the increasing cost of fossil fuels and growing rate of air pollution in the conventional energy resources, solar energy is one of the best non-conventional energy resources that replaces all the problems associated with the fossil fuels [1], [2]. The solar energy has many advantages over non-conventional energy resources such as low cost, eco-friendly, noise-free, pollution free environment by promoting green energy [3],[4]. In upcoming years, there is the huge demand of energy since the electrical loads are went on increasing from day by day as the number of customer increases [5]. Therefore, in future it will be very difficult to the utility system to fulfil the energy demand and if the demand will not be fulfilled then there will be a blackout or power failure [6]. Thus, it is required to take an inventive step to fulfil the power demand of the customers. So, for this, an alternative renewable energy resources can used as a distribution generation. Hence by installing the solar pv system as the DG there will be less burden on the utility system [7],[8]. Beside some advantages solar panel has some disadvantages such as-

1. The capital cost and equipment cost of solar pv system is high.

2. The efficiency for the energy conversion process of solar pv system is low.

3. More right of way is required for installation.

4. Weather condition dependent.

Hence in order to eliminate the affordable drawback, a hybrid based maximum power point tracking system is designed that can improve the efficiency of the solar pv system [9]. By placing the MPPT at a suitable location in the solar pv array, the efficiency of solar energy to electrical energy conversion is increased up to 60 percent. Hence, this paper focus on improving the efficiency of grid connected solar pv system by employing hybrid MPPT.

\section{DESIGN OF MODEL}

Fig.1 shows the block diagram of grid connected photovoltaic system. The system comprises of plurality of photovoltaic cells preferably a photovoltaic array connected in series with the system for extracting the solar energy and converting it into electrical energy, a buck boost converter in association with the photovoltaic array for stepping up the dc voltage coming out from the photovoltaic array, an MPPT coupled with buck boost converter for extracting the maximum power from the sun thereby improving the efficiency of the solar pv system, a voltage source converter for converting the boosted dc voltage into ac voltage and a utility grid in association with voltage source converter for transferring electrical power to different feeders and customers household.

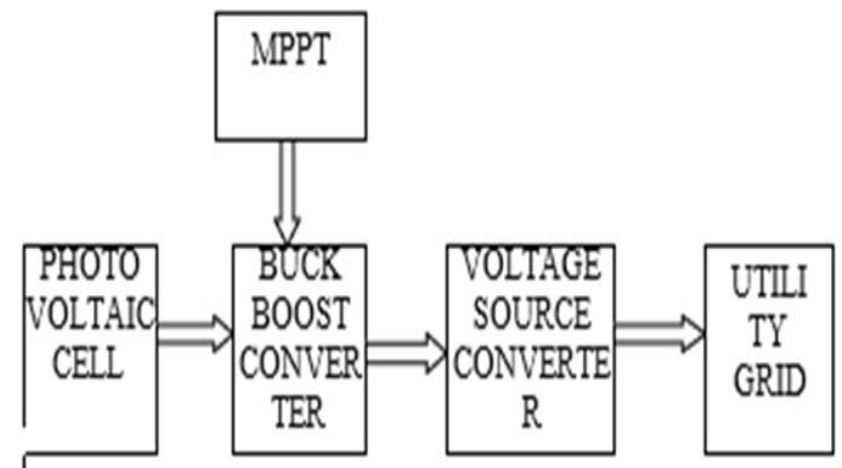

Fig. 1: Block Diagram of Grid Interconnected Photoroltaic System

Fig.2 represent the circuit diagram of solar pv cell. The solar pv cell is basically a p-n junction diode that is made up of semiconductor amorphous solid. The relation between the current and voltage is given by the equation- [10]

\section{Diode characteristic}

$$
\mathrm{I}_{\mathrm{d}}=\mathrm{Igt}_{\mathrm{gat}} *\left[\exp \left(\mathrm{V}_{\mathrm{d}} / \mathrm{VT}_{\mathrm{T}}\right)-1\right]
$$

Revised Version Manuscript Received on 10 September, 2019.

Anjali Gupta, Department of Electrical \& Electronics Engineering, Noida Institute of Engineering and Technology, Noida, U.P. India.(email: researchnietip@gmail.com)

Dr. Praveen Pachauri, Department of Mechanical Engineering, Noida Institute of Engineering and Technology, Noida, U.P. India. (email: researchnietip@gmail.com) 


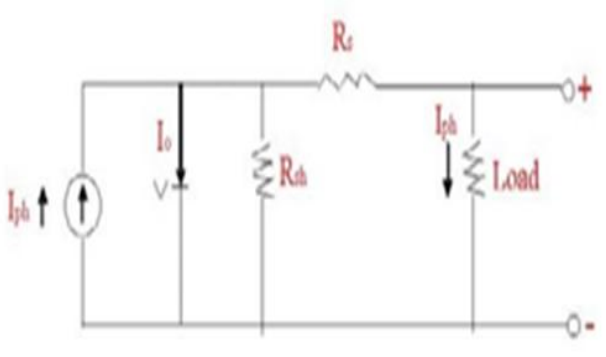

Fig. 2: Equivalent circuit of a practical Solar cell

where:

$\mathrm{I}_{\mathrm{d}}=$ diode current

(A)

$\mathrm{V}_{\mathrm{d}}=$ diode voltage $(\mathrm{V})$

$\mathrm{I}_{\mathrm{sat}}=$ diode saturation current $(\mathrm{A})$

$\mathrm{V}_{\mathrm{T}}=$ temperature voltage

The equation for temperature voltage is given by the below

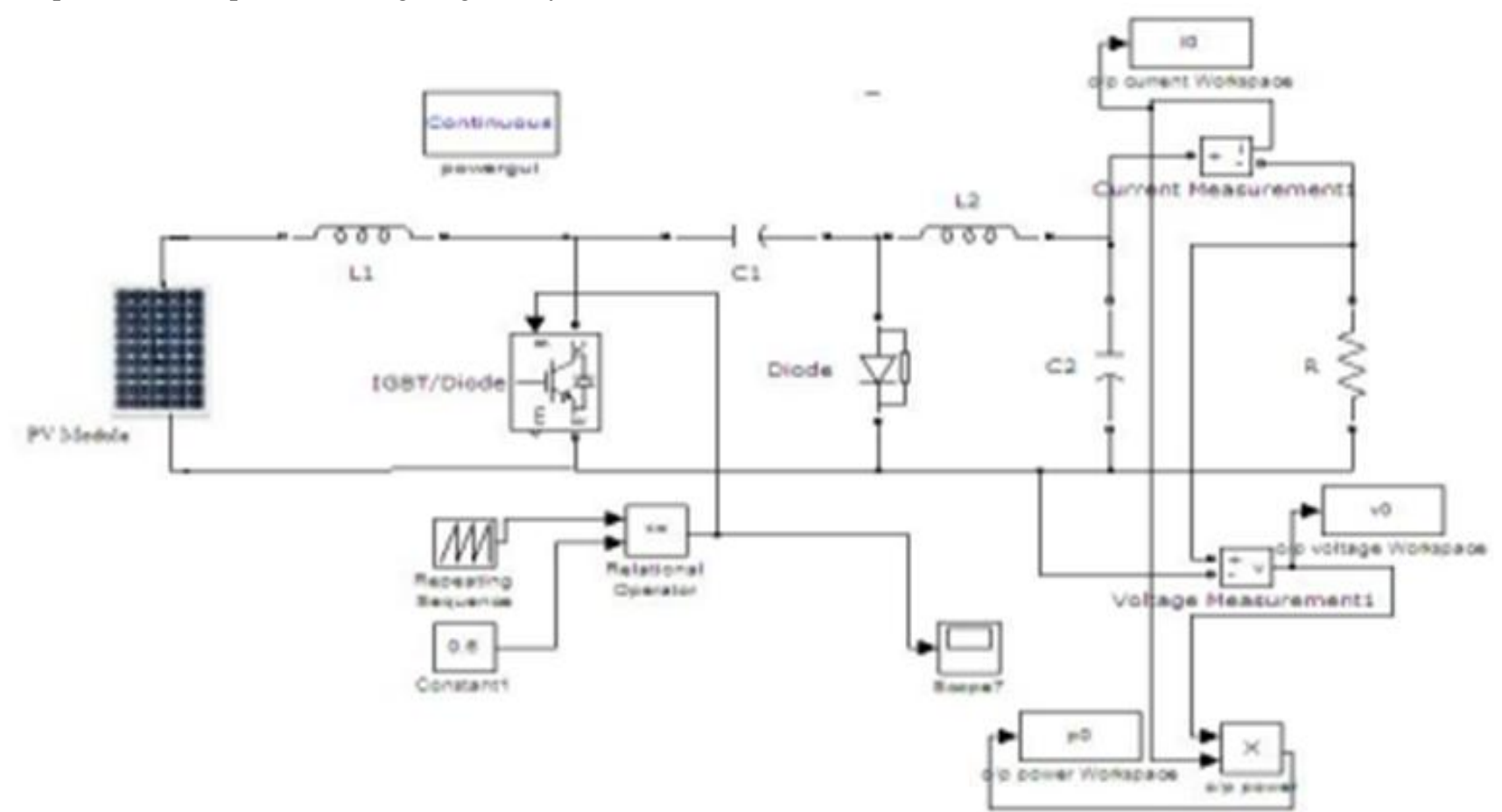

Fig.2.1 MATLAB Simulation

\section{SIMULATION RESULTS}

The following results has been obtained by performing the specific coding in MATLAB simulation software. For improving the efficiency, basically two methods are compared. First one is perturb and observe MPPT method and second is hybrid MPPT method. By coupling both the MPPTs one by one with solar pv array the following characteristics has been viewed in the MATLAB simulation.

$$
=\frac{\mathrm{kT}}{q * Q d * \text { Ncell Nser }}
$$

where $\mathrm{T}=$ cell

temperature $(\mathrm{K})$,

$\mathrm{k}=$ Boltzman

constant $\mathrm{q}=$ electron

charge $\mathrm{Q}_{\mathrm{d}}=$ diode

quality factor

$\mathrm{N}_{\text {cell }}=$ number of series-connected cells per module

$\mathrm{N}_{\text {ser }}=$ number of series-connected modules per string.

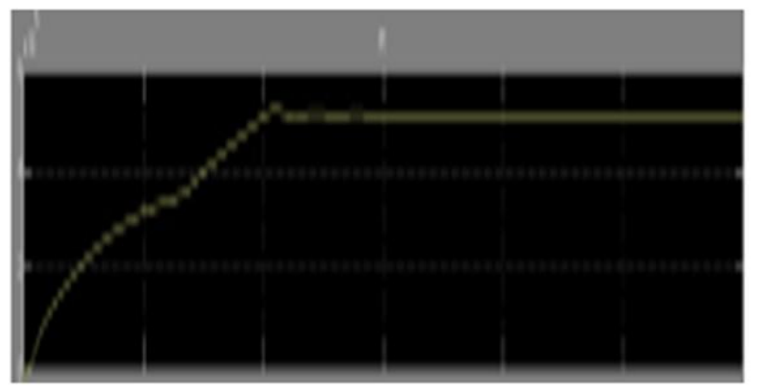

Fig.3. Output power of Grid interconnected PV system with Perturb and observe MPPT method

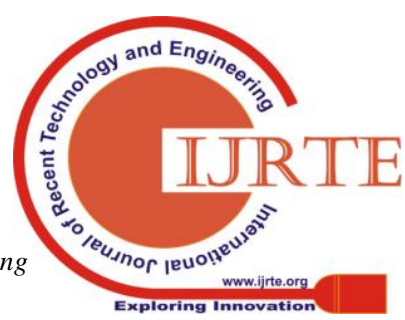


Fig.3 represents the output power of a grid connected PV system with perturb and observe MPPT method. This characteristics shows the maximum power output obtained when using the perturb algorithm. It is clear from the above characteristic that the less power is obtained when using perturb MPPT method.

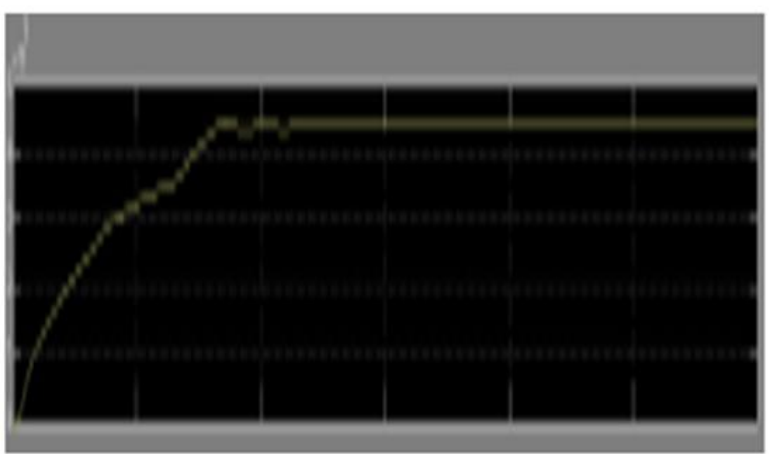

Fig.4. Output power of Grid interconnected PV system with Hybrid MPPT Method

Fig.4 represents the maximum output power of grid connected PV system with hybrid MPPT method. It is observed that when connecting the hybrid MPPT in place of perturb algorithm MPPT method the more reliable characteristics is formed. The output power obtained from hybrid MPPT method is much more than the output power obtained from perturb MPPT method.

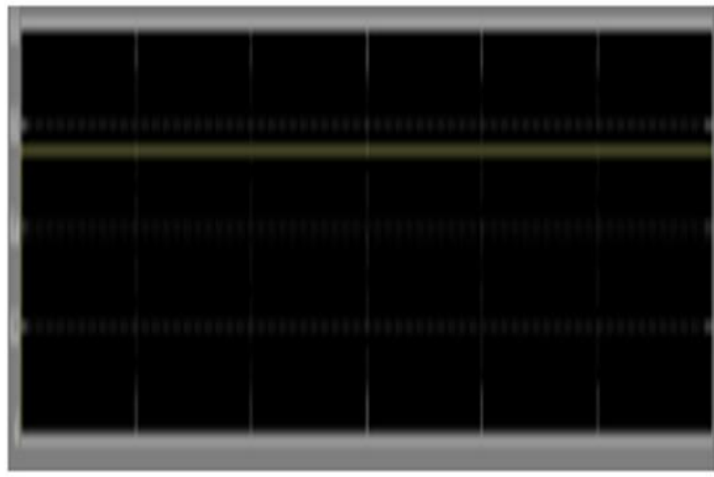

Fig.5. Duty cycle of Grid interconnected PV system with Hybrid MPPT method

Fig.5 shows the duty cycle of the grid connected PV system with hybrid MPPT method. Duty cycle represents the total time of operation of the PV system. The characteristics obtained from the above figure is constant throughout.

\section{CONCLUSION}

The grid connected solar PV system is successfully designed. For improving the efficiency of solar PV system, the maximum power point tracking system is connected to the solar PV array. The efficiency of solar PV system is tested by comparing the perturb MPPT method with hybrid MPPT method. It is observed from the above comparison that the maximum output is obtained from solar PV system by using the hybrid MPPT method in place of perturb MPPT method. Since the conversion efficiency from solar energy to electrical energy of solar PV system is very low, therefore due to this reason the use of MPPT plays a great role in improving the efficiency of solar PV system.

\section{REFERENCES}

1. N. Armaroli and V. Balzani, "The legacy of fossil fuels," Chem. - An Asian J., 2011.

2. A. Haines, R. Kovats, D. Campbell-Lendrum, and C Corvalan, "Climate change and human health: impacts, vulnerability, and mitigation," Lancet. 2006.

3. P. V. Kamat, "Meeting the clean energy demand: Nanostructure architectures for solar energy conversion," J. Phys. Chem. C, 2007.

4. M. A. Uqaili and K. Harijan, Energy, environment and sustainable development. 2012.

5. E. Almeshaiei and H. Soltan, "A methodology for Electric Power Load Forecasting," Alexandria Eng. J., 2011.

6. J. Grant, M. Eltoukhy, and S. Asfour, "Short-term electrical peak demand forecasting in a large government building using artificial neural networks," Energies, 2014

7. T. M. Razykov, C. S. Ferekides, D. Morel, E. Stefanakos, H. S. Ullal, and H. M. Upadhyaya, "Solar photovoltaic electricity: Current status and future prospects," Sol Energy, 2011

8. G. K. Singh, "Solar power generation by PV (photovoltaic) technology: A review," Energy. 2013.

9. X. Huang, S. Han, W. Huang, and X. Liu, "Enhancing solar cell efficiency: The search for luminescent materials as spectral converters," Chemical Society Reviews. 2013.

10. K. Ishaque, Z. Salam, and H. Taheri, "Simple, fast and accurate two-diode model for photovoltaic modules," Sol Energy Mater. Sol. Cells, 2011. 